УДК 342.55

DOI: $10.14451 / 2.142 .20$

\title{
НОРМАТИВНОЕ РЕГУЛИРОВАНИЕ И МЕТОДИЧЕСКОЕ ОБЕСПЕЧЕНИЕ ДОШКОЛЬНОГО ОБРАЗОВАНИЯ В СОВЕТСКИЙ ПЕРИОД
}

\author{
(C) 2020 Свечникова Вера Викторовна
}

старший преподаватель кафедры «Трудовое право и предпринимательское право»

Липецкий филиал Российской академии народного хозяйства и государственной службы при Президенте Российской Федерации, Россия, Липецк

E-mail: vera-7272@yandex.ru

\section{(c) 2020 Шауро Ирина Геннадьевна}

кандидат юридических наук, доцент, кафедра «Теория и история государства и права» Липецкий филиал Российской академии народного хозяйства и государственной службы при Президенте Российской Федерации, Россия, Липецк

E-mail: shauro@list.ru

В статье рассмотрена эволюция нормативного регулирования и методического обеспечения дошкольного образования в советский период российской истории. Данный период во многом выступает основой ныне действующей системы образования, поэтому его рассмотрение является достаточно актуальным. При этом для него характерно слияние нормативного регулирования и методического обеспечения, при котором их зачастую сложно разделить как формально, так и на практике. В результате констатируется, что методическое и правовое регулирование дошкольного образования в советский период привело к выработке ключевых принципов, актуальных и в наше время.

Ключевые слова: детский сад, дошкольное воспитание, дошкольное образование, дошкольное образовательное учреждение, история, методическое обеспечение, правовое регулирование, советский период.

Проблема эволюции дошкольного образования, определение его основных целей остается довольно острой, так как напрямую связана с коренным изменением требований государства к системе дошкольного образования. Приоритетными целями деятельности дошкольных учреждений все явственнее становится развитие «всего того, что связано с качественными приращениями к личности ребенка и со становлением его как субъекта деятельности и собственной жизни» [3, с. 57].

В связи с этим имеется объективная необходимость критического переосмысления значения образования, системы его функционирования, важности конечного результата, которое невозможно без учета прошлого опыта, особенно если он отличается глубиной и своеобразием. Ведь можно с уверенностью утверждать, что дошкольное образование в нашей стране берет свое начала со времен Киевской Руси.

Советский период становления дошкольного образования в нашем государстве во многом выступает основой ныне действующей системы. Именно поэтому его рассмотрение являет- ся наиболее актуальным. При этом для данного периода характерно своеобразное слияние нормативного регулирования и методического обеспечения, при котором их зачастую сложно разделить как формально, так на практике. Это и определило выбор предмета настоящего исследования.

Уже в ноябре 1917 года, практически сразу после учреждения Государственной комиссии по просвещению, была сформулирована «Декларация по дошкольному воспитанию» [9], ставшая первым шагом на пути построения новой образовательной системы.

В частности, декларация указывала, что дети должны воспитываться и развиваться не только в семье. Ребенок, как «объект государственного воспитания» имеет «святое право» на педагога, т.е. внимание человека, обладающего специальными знаниями и навыками по развитию детей дошкольного возраста. Также в документе высказано мнение по поводу того, что женщина мать, занимаясь воспитанием своего ребенка и вкладывая в него тепло, любовь и заботу, имеет право «быть вместе с тем свободным человеком 
и, не погрязая во всех мелочах мелкобуржуазного уклада ..., отдаться общественному труду, развитию своей личности, работе по выявлению и осуществлению своих идеалов». Таким образом, высвобождая время, ранее занятое воспитанием детей, делался шаг для фактического уравнивания женщин в правах с мужчинами. Помимо этого, данный правовой акт закрепил такие принципы дошкольного образования как бесплатность и доступность.

«Декларация по дошкольному воспитанию» содержала указание на то, что развитие ребенка, становление его как личности должно опираться на единую систему образования. С одной стороны, дошкольное образование необходимо начинать «с самого нежного возраста», ведь именно в этот период формируются интеллект, характер и иные личностные качества. С другой стороны, дошкольное воспитание рассматривалось как неотъемлемый элемент школьной системы: «самый идеал единой трудовой школы есть как бы естественное продолжение детского сада».

Принятие декларации послужило серьезным толчком на пути формирования и развития дошкольного образования. Она заложила базовые основы для дальнейшего становления идеи воспитания детей дошкольного возраста. В частности, об этом свидетельствует тот факт, что «Положение о единой трудовой школе Российской Социалистической Федеративной Советской Республики» [7] подтвердил принцип единства и преемственности системы образования, прямо закрепив, что «к единой школе присоединяется детский сад».

25 апреля 1919 года был созван Всероссийский Съезд по дошкольному воспитанию. Приоритетным направлением его деятельности стало формирование основ дошкольного образования в общегосударственном масштабе, включая выработку принципов, на которых должен базироваться образовательный процесс детей дошкольного возраста, определение основополагающих начал педагогической работы и организации учебного процесса и т.д. Другим, не менее важным направлением работы съезда, было рассмотрение существующего «положения на местах», а также выбор направления, по которому будет проходить дальнейшая основная работа по построению системы дошкольного образования детей.

Образование детей дошкольного возраста, по мнению большинства участников съезда, ста- новилось механизмом социалистического переустройства общества. Именно поэтому для повсеместной организации данного проекта была необходима колоссальная поддержка населения страны. Эта идея стала важнейшей задачей пропаганды новых форм дошкольного образования, в рамках которых огромная роль была отведена подготовке высококвалифицированных кадров педагогических работников, способных реализовать на практике все поставленные цели дошкольного воспитания [16, с. 191].

Существенным обстоятельством, во многом определившим развитие правового регулирования дошкольного образования на тот период, было упоминавшееся стремление максимально освободить родителей от обязанностей уходу за детьми, их образованию и воспитанию. Наиболее радикальные проекты предполагали разрыв отношений между родителями и детьми, при котором дети полностью переходили на общественное обеспечение и попечение. Однако на практике по результатам Всероссийского Съезда по дошкольному воспитанию было принято решение о необходимости устройства детских садов с длительным пребыванием. Именно такие детские сады и составили основу системы дошкольного образования [5]. Такой шаг, с одной стороны, позволял трудоустройство родителей (прежде всего, женщин - матерей), а, с другой стороны, содействовал всестороннему развитию ребенка. В тоже время практиковались и иные формы дошкольных учреждений: детские сады для детей с особенностями психического и физического развития, детские сады санаторного типа, детские площадки, детские комнаты при домоуправлениях, вечерние группы и т.д. [2, с. 123].

В 1930-х годах параллельно с развитием сети дошкольных учреждений велась работа по регулированию их деятельности. Например, в 1934 г. была выпущена «Программа и внутренний распорядок детского сада» [11], где были установлены единые стадии и возрастные нормы развития [17, с. 8]. В 1938 году вышло «Руководство для воспитателя детского сада» и «Устав детского сада» [13], в которых имелись приложения с перечнем оборудования по физической культуре, с примерным музыкальным репертуаром, списком детской литературы для разных возрастных групп [1, с. 15]. И это только частные примеры из довольно обширной нормативной и методической базы, сформулированной в этот 
период.

В годы Великой Отечественной войны развитие нормативной и методической базы дошкольного образования в нашей стране была, в основном, остановлено на фоне расширение сети самих учреждений. Однако уже в конце 1944 года был выпущен новый Устав детского сада, а в 1945 году - руководство для воспитателей [15]. Данные документы нашли широкое применение в силу того, что в них были закреплены основные виды деятельности детей в соответствии с возрастными, физиологическими и иными особенностями детского развития.

В послевоенный период системы дошкольного образования продолжила стремительно развиваться. Ее закрепившейся целью стала замена семейного воспитания на образование детей в воспитательных организациях дошкольного типа.

В 1953 году было издано первое обязательное для выполнения «Руководство для воспитателя детского сада» [14]. Оно включало новые требования к приемам и методам нового дошкольного образования, главной целью которого стала планомерная подготовка детей к обучению по школьной программе. Также в руководство были заложены основы дидактики - отрасли современной педагогики, изучающей истоки образования и развития. Но ключевым моментом стало то, что впервые за всю историю развития дошкольного воспитания основной формой обучения в детских садах стали обязательные занятия. Это послужило серьезным толчком на пути дальнейшего успешного функционирования и деятельности всей системы.

Уже в 1959 году были принято решение об открытии нового вида дошкольного учреждения, главную цель стало окончательное становление единой структуры образования детей раннего и дошкольного возрастов. Таким учреждением стали ясли - детский сад. В результате сформировалось непрекращающееся образование и воспитание детей до школы. Однако это вызвало необходимость соединения двух составляющих с целью конструирования общей программы обучения детей от двух месяцев до семи лет: педагогических умений и навыков, с одной стороны, и научной базы, с другой стороны. Сформулированная в результате «Программа воспитания в детском саду» 1962 года [10] приобрела такую значимость, что была утверждена и рекомендована Министерством просвещения РСФСР в ка- честве базового правового поля для работников с детьми дошкольного возраста. Впоследствии программа воспитания в детском саду стала типовой. При этом в ее периодическом редактировании принимали участие как ведущие научные учреждения, например, Академия педагогических наук СССР, так и органы власти, в частности, Управление по дошкольному воспитанию Министерства просвещения [18]. Представляется, что это однозначно свидетельствует о важности дошкольного образования детей и отношении к данному вопросу со стороны государства. Создание в 1984 году обновлённой «Типовой программы воспитания и обучения в детском саду» [19] было обусловлено естественной необходимостью совершенствования, ведь общество и его социальные устои непрерывно развивались, а требования к дошкольному образованию, соответственно, становились выше. Нельзя не отметить, что это было связано, в том числе, с развитием педагогической науки и ее значимости. Например, в положениях «Основных направлений реформы общеобразовательной и профессиональной школы» [8], в частности, подчеркивалась необходимость «обеспечить возрастающие потребности ... дошкольных и внешкольных учреждений в педагогах, воспитателях... Создавать условия для осуществления перехода на подготовку учителей и воспитателей для всех звеньев просвещения только с высшим педагогическим образованием». Также обозначалась задача создания благоприятных возможностей для развития творческой составляющей деятельности педагогов.

Коренные преобразования общественных отношений, начавшиеся в середине 80-х годов XX века, конечно, не могли не отразиться на образовании вообще и дошкольном образовании в частности. Так новая «Концепция дошкольного воспитания», одобренная 16 июня 1989 года [4], начиналась с критики берущего свое начало в 30-е годы стремления «одеть в гранитные берега детство». Она базировалась на таких принципах, как гуманизация, деидеологизация, развивающий характер образования, ориентация на личность ребенка, развитие ребенка в соответствии с его склонностями, способностями и возможностями [12]. В тоже время специально подчеркивалось, что «личностно-ориентированная модель ... не отменяет ... того факта, что общественное дошкольное воспитание является первым звеном общей системы народного образования». 
Завершающим документом в правовом регулировании советского дошкольного образования фактически стало «Временное положение о дошкольном учреждении» 1991 года [6]. Данное положение к кругу компетенции каждых дошкольных образовательных организаций добавило полномочие по свободному выбору наиболее подходящей программы «из комплекса вариативных программ». Нужно отметить, что учреждения могли вносить в рекомендованные министерством образования программы необходимые изменения и дополнения, а также создавать собственные (авторские) программы.

Подводя итог всему вышесказанному, можно сделать вывод, что правовое регулирование и методическое обеспечение дошкольного образования в советский период привело к выработке следующих ключевых принципов, актуальных и в наше время:
1. признание развития общественного (внесемейного) дошкольного образования основным направлением государственной политики в данной сфере (что не означает второстепенный характер образования и воспитания в семье, а указывает наиболее эффективный в современных условиях механизм реализации государством своих функций);

2. рассмотрение дошкольного образования в контексте единой системы образования (непрерывности образования);

3. разумное сочетание нормативного регулирования и методического обеспечения, с одной стороны, и свободы педагогической деятельности (отдельных сотрудников, коллективов и учреждений), в другой стороны;

3. индивидуальный, личностно-ориентированный подход к каждому ребенку в интересах его всестороннего и полноценного развития.

\section{Библиографический список}

1. Голдовская А. А. Развитие системы дошкольного воспитания в Москве: 1930-1950 гг.: автореф. дис. ... канд. пед. наук. М., 2011. -20 с.

2. Дианова Н.Ф. Из истории становления и развития дошкольного образования в России // Система ценностей современного общества. 2015. № 41.- С. 121-125.

3. Ежкова Н. С. Дошкольное образование: научный взгляд // Гуманитарные ведомости ТГПУ им. Л. Н. Толстого. 2016. № 1 (17).- С. 57-61.

4. Концепция дошкольного воспитания: одобрена решением коллегии Государственного комитета СССР по народному образованию 16 июня 1989 г. № 7/1 // Бюллетень Гособразования СССР. 1990. № 4, 5.

5. Народное образование в СССР: 1917-1967 / под ред. М.А.Прокофьева. М.: Просвещение, 1967.- 543 с.URL: http://www.detskiysad.ru/ped/narod.html (дата обращения: 01.02.2020 г.).

6. О временных положениях, регламентирующих деятельность учреждений (организаций) системы образования и подготовки кадров в РСФСР: постановление Правительства РСФСР от 23 февраля 1991 г. № 119.URL: https://base.garant.ru/6528082/ (дата обращения: 01.02.2020 г.).

7. Об Единой Трудовой Школе Российской Социалистической Федеративной Советской Республики: декрет Всероссийского Центрального Исполнительного Комитета от 16 октября 1918 г. // Собрание узаконений РСФСР. 1918. № 74. Ст. 812.

8. Об основных направлениях реформы общеобразовательной и профессиональной школы: постановление Верховного Совета СССР от 12 апреля 1984 г. № 13-ХІ // Ведомости Верховного Совета СССР. 1984. № 16. Ст. 237.

9. Приложение № 1 к протоколу заседания № 57 (п. 2) Коллегии Народного комиссариата по просвещению РСФСР. Декларация по дошкольному воспитанию // ГА РФ. Ф. А-2306. Оп. 1. Д. 319. Л. 26-27 об.

10. Программа воспитания в детском саду. М.: Учпедгиз, 1962.- 192 с.

11. Программы и внутренний распорядок детского сада. М.; Л.: Наркомпрос РСФСР - Учпедгиз, 1934. - 175 с.

12. Рубинчик Ю. С. Этапы развития советской системы дошкольного образования // Гуманитарные, социальноэкономические и общественные науки. 2015. № 11. C.321-324. - URL: https://online-science.ru/userfiles/file/ s4nt9dzhtgyrp4vg3puln59ufxk1e0go.pdf (дата обращения: 01.02.2020 г.).

13. Руководство для воспитателей детского сада. Устав детского сада. М.: Наркомпрос РСФСР, 1938. - 117 с.

14. Руководство для воспитателя детского сада. М.: Учпедгиз, 1953.- 171 с.

15. Руководство для воспитателя детского сада. Устав детского сада. М.: Учпедгиз, 1948. - 148 с. 
16. Салова Ю.Г. Съезды и конференции по дошкольному воспитанию 1920-х годов о роли семьи и коллектива в становлении личности ребенка // Уваровские чтения-VII: семья в традиционной культуре и современном мире: материалы всероссийской научной конференции. Муром. 29 апреля - 1 мая 2008 г. Владимир: Транзит ИКС, 2011.- С.190-194.

17. Соломенникова О.А. Разработка программных документов для ДОУ на разных этапах развития дошкольного образования // Современное дошкольное образования. Теория и практика. 2009. № 6. - C.8-13

18. Телегин М.В. Преимущества советской «программы обучения и воспитания в детском саду» перед «инновационными» дошкольными образовательными программами // Детский сад от А до Я. 2012. № 4 (58). - С. 4-44. - URL: http://www.mtelegin.ru/pedagogika/sovetprog (дата обращения: 01.02 .2020 г.).

19. Типовая программа воспитания и обучения в детском саду / под ред. Р. А. Курбатовой, Н. Н. Поддьякова. М.: Просвещение, 1984.- 174 с. 